\title{
Nowa starożytna Jerozolima - miasto wykreowane przez brytyjskie władze Mandatu Palestyny
}

\author{
Jerusalem - a new ancient city created \\ by the authorities of the British Mandate \\ for Palestine
}

\section{Streszczenie}

Wojny są nośnikiem zmian urbanistycznych. Nie chodzi tylko o towarzyszące im zniszczenia, ale także o mechanizmy związane z ich społecznymi skutkami, w tym i swoiście rozumianej kreacji architektonicznej i urbanistycznej. Szczególnie widoczne stało się to po zajęciu przez oddziały brytyjskie Jerozolimy w grudniu 1917 roku. W kontekście wydarzeń mających miejsce na Bliskim Wschodzie towarzyszyła temu procesowi ekspansja wzorców zachodnich o podłożu fantasmagorii historycznej.

Słowa kluczowe: Towarzystwo Pro-Jerozolimskie, europeizacja, kreacja parahistoryczna, zmiany krajobrazowe, orientalizm

Abstract

War is a unique carrier of urban changes - not only with regard to the destruction that accompanies them but also in the context of the mechanisms associated with their social consequences. Not only for the destruction resulting from military actions but also arising from the mechanisms related to their political and social effects, including architectural and urban creation in a very specific sense. For these reasons, the Great War of 19141918 is now generally seen not only as a traumatic political and military experience on a universal scale but also as a trigger that gave rise to the great social changes that occurred in the twentieth century. The cultural change then forced on leaders, to take many different shapes often reaching for the clearly recognisable symbolism at the intersection of urban planning, architecture, historical phantasmagoria and religion. This became particularly visible during the so-called Palestinian campaign of General Edmund Allenby and after British troops captured Jerusalem in December 1917.

Keywords: Pro-Jerusalem Council, orientalism, Europeanisation, parahistorical creation, landscape changes 


\section{WSTĘP}

Brytyjskie oddziały tzw. Egipskich Sił Ekspedycyjnych (Egyptian Expeditionary Force) pod dowództwem gen. Edmunda Allenby'ego wkraczające do Jerozolimy i, jak wówczas głoszono, „wyzwalające miasto spod ciężkiej ręki panowania osmańskiego”, były zwiastunem nadchodzących głębokich zmian. Nie wdając się w szczegóły z zakresu historii wojskowości, należy nadmienić, iż 11 grudnia 1917 roku gen. Allenby, wytrawny polityk, dyplomata oraz zręczny dowódca i 34 w historii zdobywca Jerozolimy, pokornie wszedł pieszo do miasta przez Bramę Jaffajską - aby okazać szacunek, a także przekazać opinii światowej fakt, że Brytyjczycy nie postrzegali mieszkańców Świętego Miasta jako podbitych wrogów, ale raczej ofiary osmańskiego ucisku - o czym skwapliwie informował np. londyński „Daily Sketch”, który w numerze z 11 grudnia na pierwszej stronie ogłaszał, iż „Święte Miasto jest w brytyjskich rękach” Brytyjczycy byli przy tym przekonani, iż przestrzeń pozostająca przez czterysta lat pod rządami osmańskimi musiała zostać odpowiednio zmieniona, aby znów stać się uniwersalnym miastem pod kontrolą cywilizacji zachodniej. Misja ta miała rozpocząć się od wprowadzenia zmian w substancji urbanistycznej miasta.

\section{RELIGIJNE I KULTUROWE GENEZY ZMIAN - ORIENTALISTA-AMATOR RONALD STORRS I JEGO WIZJA BIBLIJNO-ŚREDNIOWIECZNEGO MIASTA}

Komplikacje związane z faktem, iż Jerozolima była postrzegana wyłącznie jako symbol religijny, dotyczyły również samego gen. Allenby’ego, który niemal natychmiast po wkroczeniu jego oddziałów do miasta zapewnił wszystkich mieszkańców, że ich życie i skarby dziedzictwa związane z którąkolwiek religią będą chronione. Sytuacja stawała się nieco paranoiczna, a Brytyjczycy z jednej strony unikali - jak mogli - poruszania kwestii religijnych, z drugiej zaś zdawano sobie sprawę, że nie dało się od nich w wypadku Jerozolimy uciec. Z jednej strony unikano analogii do wypraw krzyżowych i podkreślano poszanowanie kulturowe muzułmańskiej istoty miasta, z drugiej zaś brytyjscy decydenci zaplanowali prace, których celem było znaczące przeobrażenie krajobrazu urbanistycznego i kulturowego Jerozolimy.

Brytyjczycy przynieśli bowiem ze sobą fantasmagoryczny obraz zbudowany z różnych źródeł sprowadzający się do swoiście pojmowanej plastyczności narracji, której atrakcyjność i wszelkie walory religijności przekazu historycznego z jednej strony sprowadzały się do funkcji dydaktycznej, z drugiej zaś rozwijały wyobraźnię, stanowiąc istotę zjawiska, jakim była całkowicie ahistoryczna wizja Jerozolimy. Opierało się to na dostępnych wcześniejszych relacjach z podróży, tekstów historycznych i fikcyjnych, obrazów orientalistycznych i lektur biblijnych. Było to spowodowane faktem, iż wielu Brytyjczyków, którzy znaleźli się w omawianym okresie w Jerozolimie, było wręcz „rozczarowanych”, ponieważ miasto "było tak inne niż to, którego się spodziewali. Drogi były jeszcze gorsze niż hotele, a zamiast Świętego 
Miasta znaleźli jedynie koszmarny odór" - jak napisał wojskowy gubernator Jerozolimy w latach 1918-1926 Ronald Henry Amherst Storrs². „Jerozolima to malownicze, ale brudne średniowieczne miasto z rozległymi przedmieściami; źle zbudowane, niezamieszkałe, z niewygodnymi i prowadzącymi donikąd drogami"3. Ta na poły romantyczna i ahistoryczna wizja miasta koncentrowała się na tych elementach, które w ich ocenach emanowały historią i świętością: Kopuła na Skale, kościół Grobu Świętego i Ściana Płaczu. Oprócz tego udzielał im się nastrój miasta „zaklęty” w budynkach, ścianach i ruinach miasta - a nie jego mieszkańcach. Spowodowało to wytworzenie sytuacji, w której brytyjscy decydenci - ze Storrsem na czele znaleźli „autentyczną Jerozolimę” z czasów wypraw krzyżowych ${ }^{4}$. Problemem pozostawał jedynie fakt, iż te pomniki architektury i kultury zostały „zakryte” zabudową okresu późnoosmańskiego.

Znany ze swego doktrynalnego anglikanizmu Storrs uznał, iż ma do wypełnienia misję dziejową. Dostrzegał także konieczność przekonania do swych pomysłów jak najszerszego grona i postanowił odwołać się do brytyjskich tradycji w tym względzie - mianowicie do powołanego w roku 1895 w Wielkiej Brytanii National Trust for Places of Historic Interest and Natural Beauty, którego celem była ochrona środowiska i dziedzictwa historycznych miejsc i przestrzeni w Anglii, Walii, Szkocji i Irlandii Północnej „na zawsze i dla wszystkich”. W celu realizacji swych planów i na podstawie doświadczenia właśnie tej organizacji Storrs powołał w Jerozolimie komitet mający strzec „zachowania właściwej” architektury miasta Towarzystwo Pro-Jerozolimskie (Pro-Jerusalem Council) ${ }^{5}$. Było to ewidentne obejście zakazu przeprojektowywania lub zmiany praw własnościowych, który wprowadzono w ramach okupacji wojskowej. Za eksponowaną na spotkaniach Towarzystwa wizją Storrsa szły również konkretne posunięcia. Stwierdził on, że np. wieża zegarowa nad Bramą Jaffajską, przez którą wszedł do miasta gen. Allenby, drażniła go bardzo. W opinii Storrsa koniecznym było usunięcie wszelkich współczesnych nawarstwień urbanistycznych, które nie licowały z jego wizją biblijnej i krucjatowej estetyki będącej zlepkiem wyobrażeń, znajomości klasyki i starożytności oraz świadomości posiadania pełnej kontroli nad miastem ${ }^{6}$, podobnie jak czynił to jego wielki poprzednik Poncjusz Piłat. Chociaż powojenna sytuacja militarna i polityczna związana z brytyjską okupacją w Jerozolimie nie dawała Storrsowi (w przeciwieństwie do Piłata) całkowicie wolnej ręki do wprowadzenia w życie własnych wizji, to jednak zapewniła mu możliwość kontrolowania prac związanych z konieczną przebudową miasta ${ }^{7}$. Tym samym głównym zadaniem Towarzystwa stało się nie odtworzenie zniszczonej i unowocześnienie istniejącej infrastruktury, ale „ocalenie starożytności miasta, zachowanie jego udogodnień, ochrona starożytnego miasta przed przemysłowym zbezczeszczeniem i rozplanowanie współczesnego miasta z jakimś planem i odpowiadającą mu godnością"”. 


\section{WIELKI PLAN ARCHITEKTONICZNO-URBANISTYCZNY DLA JEROZOLIMY}

\subsection{POLITYKA HISTORYCZNEJ NIESPÓJNOŚCI W SŁUŻBIE KULTUROWEJ KRUCJATY BRYTYJSKICH ELIT RZĄDZĄCYCH}

Wizje przebudowy Jerozolimy forsowane przez Storrsa opierały się w zasadzie na warunkach koniecznych. Miasto w istocie wymagało szeregu prac i sporych nakładów, w tym samym bowiem czasie gen. Allenby powierzył Williamowi McLeanowi opracowanie programu planowania miasta. Założenia były ze wszech miar słuszne, gdyż wycofujące się oddziały osmańsko-niemieckie zabrały bądź zniszczyły nie tylko większość podstawowych zapasów (w tym żywność, paliwo i lekarstwa), ale i infrastrukturę komunikacyjną. Drogi zostały zrujnowane, a znaczna część linii kolejowej rozebrana. Tym samym pierwszy brytyjski urbanista William McLean, który przybył do Jerozolimy jeszcze przed zakończeniem I wojny światowej, uznał, iż istniała pilna potrzeba przebudowy części infrastruktury Jerozolimy. Nakłady były konieczne, a celem McLeana była „ochrona starego miasta Jeruzalem i świętych miejsc w jego pobliżu przed nowoczesnymi wkroczeniami i zachowanie istniejących udogodnień"9. Jednak z czasem działania te nabrały rozmachu, pomimo łagodności jego pierwotnych założeń.

Jeszcze przed objęciem przez Storrsa urzędu jego poprzednik pierwszy wysoki komisarz miasta Herbert Samuel uznał planowanie urbanistyczne za kluczowe dla wprowadzenia nowoczesnego rozwoju do opanowanej przez Brytyjczyków Palestyny, widząc w tym remedium na traumę wywołaną doświadczeniami Wielkiej Wojny. „Planowanie miast jest jednym z najważniejszych ruchów współczesnego świata. [...] We wszystkich krajach ludzie zaczynają poświęcać się tego rodzaju planom, aby uniknąć zła, które spadło na naszych przodków. Środowisko jest ważnym czynnikiem i naszym zadaniem powinna być poprawa tego środowiska"10. Nie było to podejście nowe, gdyż opinia Samuela była głęboko zakorzeniona w podejściu, iż urbanistyka była wówczas stosunkowo nową praktyką, która pojawiła się pod koniec XIX w. jako element naukowy w tworzeniu bardziej produktywnej, higienicznej i stabilnej politycznie substancji społeczno-przestrzennej, jakim było miasto. Tym samym brytyjskie planowanie odnośnie do Jerozolimy zostało usystematyzowane wokół czegoś, co wydawało się być dwoma sprzecznymi celami:

- uczynienie miasta bardziej nowoczesnym i uporządkowanym, jednym słowem bardziej „europejskim”;

- przywrócenie miasta do jego religijno-historycznych korzeni, to znaczy, jak wyglądało, zanim władzę w nim przejął "okrutny Turek”.

Te wydawać by się mogło całkowicie wykluczające się podejścia miały jednak pewną wspólną cechę - europejskość wspartą działaniami rządu Jego Królewskiej Mości dzięki ustawie o ochronie zabytków z 1882 roku i ustawie o zabytkach z 1913 roku. Znamiennym pozostawał fakt, iż Wielka Brytania wprowadziła zapisy obu tych aktów prawnych w swoich 
koloniach, zwłaszcza w Indiach, implementując zapisy urbanistyczne i zarządzenia wprowadzone jeszcze przed I wojną światową w Kalkucie (1911) i New Delhi (1912), podczas wojny w Bombaju (1915) i po wojnie w Madrasie (1920). Ta nagła eksplozja urbanistyczna doprowadziła do gwałtownego zainteresowania się tymi kwestiami i przemieszczania się ekspertów w całym imperium; wielu planistów i doradców, którzy przybyli w latach 1918-1919 do Palestyny, miało doświadczenie w planowaniu lub zarządzaniu innymi przestrzeniami w koloniach oraz strefach odpowiedzialności i kontroli Wielkiej Brytanii. Osoby związane z planami przebudowy Jerozolimy miały odpowiednie doświadczenie: wspomniany William McLean przybyły do Palestyny pracował wcześniej jako inżynier miejski w egipskiej Aleksandrii, jego następca - Patrick Geddes, pracował w Indiach, zaś kolejny z wizjonerów C.R. Ashbee - przybył do Jerozolimy również z Egiptu ${ }^{11}$.

Tym samym ich pierwszym celem było zbudowanie miasta, które według ówczesnych standardów brytyjskich „miało sens” - z uporządkowanym systemem ulic, budynków, przestrzeniami publicznymi i „zabytkami”, które musiałyby zostać nazwane, zorganizowane i dostosowane do siebie, tak jak miało to miejsce np. w Londynie. Drugi cel polegał na usunięciu warstw niedawnego rozwoju lokalnego, tak aby „odkryć” i zachować chwalebną, religijną i odpowiednio zmodyfikowaną kulturowo przeszłość miasta. McLean, wykorzystując nowe techniki planowania urbanistycznego i zachowania substancji historycznej, miał za zadanie rozwiązać tę sprzeczność.

\subsection{STARE DZIELNICE I NOWE STREFY JAKO ELEMENTY IDEALNEGO UKŁADU URBANISTYCZNEGO}

Chociaż sam nie był architektem ani urbanistą, Ronald Storrs został podczas służby w Egipcie członkiem kairskiej Comite pour la Conservation des Monuments Arabes. Tam też ugruntowało się jego podejście do specyficznie postrzeganego orientalizmu i gdy w roku 1917 Allenby mianował go wojskowym gubernatorem Jerozolimy, ten zdawał sobie sprawę z możliwości, które dawała mu nowa funkcja: „Nie mogę udawać, że opisuję lub analizuję moją miłość do Jerozolimy. [...] Dla mnie Jerozolima stała i stoi samotnie wśród innych miast świata. Istnieje wiele stanowisk o większej władzy i renomie w obrębie Imperium Brytyjskiego i poza nim, ale w pewnym sensie, którego nie potrafię wyjaśnić, po Jerozolimie nie ma już żadnego awansu"12.

Stare Miasto w Jerozolimie miało zostać przekształcone na obraz tego, jak brytyjscy planiści pod wpływem obrazów z Biblii i pism religijnych oraz opisów kronikarskich z czasów wypraw krzyżowych wyobrażali sobie „Święte Miasto” ${ }^{13}$. Nowe Miasto zaś miało odpowiadać wzorcom europejskim, a wizja uczynienia z prowincjonalnej Jerozolimy kulturalnej wizytówki brytyjskiego imperializmu na Bliskim Wschodzie owładnęła Storrsem całkowicie ${ }^{14}$ niemal na każdym poziomie zmian - od identyfikacji wizualnej po układ urbanistyczny. Marginalną, ale dobrze 
uwidaczniającą podejście Storrsa, jest np. kwestia ceramiki - „najpierw podjęto tę kwestię w celu odnowienia Kopuły na Skale, a później upowszechnili ją jako symbol lokalnego orientalizmu, nawet jeśli została wyprodukowana przez chrześcijańskich armeńskich rzemieślników pod brytyjskim nadzorem"15. Storrs do Jerozolimy sprowadził np. ormiańskiego garncarza Davida Ohannessiana, po tym jak przeprowadził on na dużą skalę przebudowę w Yorkshire domu swojego przyjaciela Marka Sykesa. Tym samym charakterystyczne trójjęzyczne znaki uliczne w całej Jerozolimie zostały zamówione właśnie w warsztacie Ohannessiana.

Pierwszy plan urbanistyczny nowej Jerozolimy został opracowany przez Williama McLeana już w roku 1918. Dzielił on Jerozolimę na cztery strefy:

1) Stare Miasto, w którym należało zachować „średniowieczny aspekt” poprzez zakaz wszelkiej nowej zabudowy;

2) strefę niezwiązaną z zabudową wokół Starego Miasta, w której niepożądane budynki zostałyby usunięte, a obszar po nich pozostawiony do odtworzenia stanu naturalnego;

3) obszar na północ i wschód od Starego Miasta, gdzie budynki można było wznosić tylko za specjalną zgodą;

4) obszar na południe i zachód od Starego Miasta, który został przeznaczony na nowoczesny rozwój.

Tego rodzaju podejście do kwestii wydzielenia krajobrazowego dwóch niezależnych bytów w obrębie jednego zespołu urbanistycznego zostało jednak w zasadzie zaimportowane, gdyż tego rodzaju podziały miast przypominały planowanie kolonialne w innych częściach regionu, szczególnie we francuskiej Afryce Północnej. Opracowany w tym duchu dla Jerozolimy plan miał tę samą rozgałęzioną formę, promowaną np. w Maroku, ale znalazła się w nim jedna zasadnicza różnica. W ramach francuskiego planowania urbanistycznego „zacofaną" i archaiczną natywną medinę pozostawiono samą sobie, ponieważ francuscy urbaniści koncentrowali się na budowie oddzielnej i całkowicie nowoczesnej europejskiej ville moderne. W brytyjskim planowaniu przebudowy Jerozolimy Stare Miasto nie miało pozostać swoistym skansenem życia orientalnego ze wszystkimi swoimi historycznymi i religijnymi miejscami, ale miało zostać pozbawione wtórnych - zdaniem planistów - nawarstwień. Tym samym było ono definiowane jako paradygmatyczne Święte Miasto, przedmiot, dla którego opracowano kolonialne dyscypliny z zakresu archeologii i ochrony wizji historii wypraw krzyżowych ${ }^{16}$.

Tym samym tak postrzegane planowanie miało doprowadzić do wyraźnego oddzielenia substancji Starego Miasta od reszty nowej Jerozolimy, szczególnie od tego, co miało stać się w zamysłach Storrsa tzw. Zachodnią Jerozolimą, gdzie można by zbudować nowoczesne miasto według wzorców europejskich, i wydzielenia koniecznego zaplecza rolniczego na wschód od miasta. Przyjęty na podstawie tych wytycznych podział został zachowany i dopracowany w dalszych planach urbanistycznych już autorstwa Patricka Geddesa (1919) i C.R. Ashbee'ego (1922), a jego wpływ pozostaje widoczny do dziś17. 
Należy podkreślić, iż żaden jednak ze wspomnianych urbanistów nie działał w próżni architektonicznej i kulturowej i na pierwszy rzut oka ich wizja miasta mogła (i nadal może) wydawać się potwierdzać podział przestrzeni, który już istniał. W końcu mury miejskie i górująca nad miastem cytadela stanowiły część systemu obronnego Starego Miasta. Ten charakterystyczny fragment fortyfikacji został wzniesiony z rozkazu Sulejmana Wspaniałego w roku 1532 jako twierdza zabezpieczająca jedną z ważniejszych bram Jerozolimy - wspomnianą wcześniej Bramę Jaffajską, i zamykał obszar najstarszej części miasta o powierzchni ok. 0,9 km². Znamiennym przy tym pozostawał fakt, iż Storrs uważał, że odbudowa cytadeli stanowić będzie właściwe podkreślenie rangi władz brytyjskich w Jerozolimie ${ }^{18}$.

Należy także podkreślić, iż pragmatyzm polityczny w najmniejszym nawet stopniu nie przekładał się na poszanowanie istniejącego układu kulturowo-etnicznego w Starym Mieście. Brytyjczycy nie zwracając uwagi na istniejące tam tradycyjne podziały - kwartał ormiański, żydowski, muzułmański oraz chrześcijański - stwierdzili, że Jerozolima jako układ urbanistyczny może funkcjonować skutecznie tylko wtedy, gdy jej nowoczesne elementy zostaną oddzielone od tradycyjnych miejsc o charakterze religijnym i historycznym. Nieistotnym w zasadzie wydawał się przy tym fakt, iż rozróżnienie między tymi przestrzeniami było łatwe do przeprowadzenia wyłącznie na papierze, dużo trudniej było uporządkować je w rzeczywistej przestrzeni ścisłego podziału własnościowego opartego na wzorcach religijnych i etnicznych. Nie zmieniło to jednak faktu, iż działania korekcyjne zostały wprowadzone w substancji Starego Miasta.

Kwestie urbanistyczne i zamiary Storrsa względem konieczności wprowadzenia zmian były - jak to już zostało wspomniane - podyktowane skrajnie wrogim stosunkiem do Turków. W swoim pamiętniku Storrs opisywał, jak np. pod rządami osmańskimi wspaniały średniowieczny bazar „przerodził się przez zaniedbanie w publiczną latrynę. Sklepy były pełne nieporządków, gruz czasami leżał na wysokości pięciu stóp, a malownicze drzwi były rozbite przez Turków na drewno opałowe. Odnowiliśmy sklepienia, pokrycia dachowe i ściany Suqu [arab. targu - KM], sprowadziliśmy krosna ${ }^{19}$, a pod koniec pierwszego roku zatrudniliśmy na zasadzie samowystarczalności około siedemdziesięciu osób"20.

Efektami tych działań było usunięcie wspomnianej wieży zegarowej znad Bramy Jaffajskiej. Powstająca od roku 1907 na szczycie historycznej bramy bardzo ozdobna wieża zegarowa według założeń osmańskich miała stać się elementem rozwijającej się wówczas dzielnicy biznesowej w górnej części doliny Hinnom²1. Zgodnie z intencją władz osmańskich miała być ona jedną z około stu takich wież zegarowych zbudowanych w całym Imperium Osmańskim z okazji 25-lecia panowania sułtana Abdülhamida II i przewidywano jej ukończenie w roku 1900²2. Jednak ze względu na wysoki koszt budowy (ok. 20000 franków) i szczupłe środki finansowe władz miasta pieniądze nie zostały zebrane na czas, a sama wieża zegarowa została ukończona dopiero w roku $1908^{23}$. Wieża zegarowa przetrwała zaledwie czternaście lat i została zburzona przez Brytyjczyków w roku $1922^{24}$. Sam zegar został przeniesiony na nowoczesną, o wiele mniej ozdobną wieżę przy ówczesnym Allenby Square (obecnie IDF 
Square), w pobliże budynków poczty i urzędu miasta ${ }^{25}$. Brytyjczycy dokonali także szeregu innych korekt krajobrazowych w rejonie wspomnianej bramy - jeszcze w roku 1944 zburzyli rząd domów wzniesionych pod zewnętrzną ścianą muru miasta prowadzącego do Bramy Jaffajskiej od północy. Wówczas też jako argument podniesiono konieczność zachowania „historycznego obrazu Jerozolimy”26.

Nie bez znaczenia także w tych działaniach pozostawały szeroko rozumiane kwestie polityczne i wiążące się z nimi zagadnienia osadnicze. Ze względu na wagę Deklaracji Balfoura dla brytyjskiej polityki planiści musieli być zapewne w pełni świadomi potrzeb osadniczych nie tylko elit brytyjskich, ale także przybywających do powołanego pod auspicjami Ligi Narodów brytyjskiego Mandatu Palestyny osadników żydowskich. Z tego też powodu Nowe Miasto było od samego początku postrzegane nie tyle jako przestrzeń dla osadnictwa brytyjskiego, która była w zasadzie nieistotna przez cały okres funkcjonowania Mandatu, ale jako strefa przeznaczona do osadnictwa kolonialnego napływających tam Żydów.

W tym też duchu powstała np. jedna z dzisiejszych dzielnic nowej Jerozolimy - Rehavia. Założona w 1922 roku dzielnica Rehavia miała stać się „przedmieściem ogrodowym” dla rodzin żydowskich. Stworzony przez architekta Richarda Kaufmanna (który zaplanował również wiele innych nowych dzielnic Jerozolimy) plan zakładał, że każda rodzina miała mieć własny dom i ogród, a wiele domów zbudowano w zmodyfikowanym stylu Bauhaus - z małymi dachami nad drzwiami i oknami - przydatnymi w subtropikalnym klimacie Mandatu Palestyny, zaokrąglonymi balkonami, wejściami po bokach budynków i szczegółami w stylu art deco 27 .

Inne dzielnice Jerozolimy powstałe również w latach 20. i 30. XX w., jak: Talbiya, Katamon, Abu Tor i Baka, były zamożnymi enklawami zamieszkanymi głównie przez chrześcijańskich Arabów. Eklektyczne elementy architektoniczne zdobiły tamtejsze budynki. Sięgnięto po motywy renesansowe, mauretańskie i arabskie oraz armeńskie dekoracje ceramiczne ${ }^{28}$.

\section{AHISTORYCZNA KREACJA PRZESTRZENI HISTORYCZNEGO MIASTA}

Pierwotny plan McLeana z roku 1918 przewidywał korekty krajobrazowe poprzez oczyszczenie budynków przylegających do murów Starego Miasta, usunięcie stamtąd sklepów i wieży zegarowej przy Bramie Jaffajskiej oraz odbudowę części muru miejskiego. Oprócz tych prac Storrs przedstawił również zbiór przepisów, które obejmowały m.in.: brak możliwości budowy jakiegokolwiek budynku, który miałby być umieszczony na linii horyzontu Góry Oliwnej lub na południu miasta; żaden budynek nie mógł mieć więcej niż jedenaście metrów wysokości nad poziomem gruntu; dachy budowane lub kryte musiały być kamieniem lub innym zatwierdzonym materiałem; niedozwolone było stawianie budynków przeznaczonych do celów przemysłowych. Gen. Allenby zatwierdził ten plan 22 lipca 1918 roku²9. 
Próba przeprojektowania Jerozolimy przez McLeana, tak aby była zgodna z europejskimi założeniami, załamała z trudem odbudowywany po wojnie istniejący układ funkcjonalny. McLean składając plan, dołączył do niego notatkę wyjaśniającą, w której stwierdzał, że jego plan „miał na celu zachowanie średniowiecznego aspektu Starego Miasta i otoczenie go pasem ziemi, który powinien pozostać w swoim naturalnym stanie, o ile byłby wówczas praktyczny. Ponadto wszelkie konstrukcje, które mogłyby zostać wzniesione w pasie położonym poza tym obszarem, powinny pozostać w harmonii i skali ze Starym Miastem" ${ }^{30}$. Storrs określił również restrykcyjne normy prawne w kwestiach ewentualnej zabudowy - nikt nie mógł „,wyburzyć, wznieść, zmienić lub naprawić konstrukcji jakiegokolwiek budynku w mieście lub jego okolicach w promieniu 2500 metrów od Bramy Damasceńskiej, dopóki nie uzyska pisemnego zezwolenia od władz, a karą za naruszenie była grzywna nieprzekraczająca £200”31. Geddes, który przygotował kolejną modyfikację planu, promował praktykę swoiście rozumianej architektonicznej „chirurgii zachowawczej” w celu usunięcia nowoczesnego rozwoju ze starożytnych miejsc w mieście, a Ashbee, który podążył za nim, zażądał „zburzenia” wszystkich domów i przedsiębiorstw przylegających do starożytnego muru. Te formy historyzmu pozbawiły istniejącą substancję miasta jej wyjątkowego charakteru i pomnożyły liczbę wzorców do naśladowania. Zastosowane wówczas techniki planowania urbanistycznego i konserwacji parahistorycznej zniszczyły autochtoniczne elementy krajobrazu Jerozolimy. Należy jednak podkreślić, iż działania tego rodzaju były spowodowane głębokimi pobudkami o charakterze religijno-politycznym.

Wprowadzone wówczas szczególne rozporządzenie z 1921 roku w sprawie planowania urbanistycznego, które wraz z jego różnymi poprawkami kontrolować miało wszystkie plany urbanistyczne i budowlane, dotyczyło nie tylko Jerozolimy, ale całego Mandatu Palestyny. Zgodnie z brytyjską ustawą o mieszkalnictwie i urbanistyce z 1919 roku rozporządzenie to całkowicie zakazało prowadzenia nieplanowanej rozbudowy i wymuszało przygotowanie szczegółowego lokalnego planu przestrzennego dla każdego miasta w Mandacie Palestyny oraz do powołania lokalnych komitetów w celu uregulowania kwestii form architektonicznych planowanych budynków i ustalenia trybów wydawania odnośnych pozwoleń. Rozporządzenie to systematyzowało, jaki rodzaj inwestycji miał pierwszeństwo, stwierdzając, że od gmin oczekuje się wywłaszczenia gruntów i budynków na cele służące ogółowi społeczeństwa, takie jak np. poszerzenie istniejących dróg lub budowa nowych ciągów komunikacyjnych, na komunalne potrzeby mieszkaniowe, organizacja ogrodów lub placów publicznych, budynków użyteczności publicznej - w tym szpitali, szkół, muzeów lub cmentarzy.

Tym samym oparta na fantasmagorii historycznej działalność Storrsa zyskała odpowiednią podbudowę ideologiczną, prawną i wsparcie czynników rządowych. To pokazuje dobitnie, że przebudowa Jerozolimy wcale nie była oderwanym od szerszego kontekstu wybrykiem grupy lokalnych decydentów brytyjskich, ale uzasadnionym kulturowo, politycznie i religijnie programem. Z punktu widzenia dzisiejszych standardów było to działanie wręcz barbarzyńskie, jednak na początku lat 20. XX w. postrzegano to zupełnie inaczej. 
Paradoksalnie jednak działania tego typu miały i pozytywne skutki i nadały również nowe cechy historycznym elementom zachowanej zabudowy. Na przykład decyzja Ashbee'ego o odtworzeniu starej osmańskiej ścieżki dozorowej na szczycie murów i wałów - która była wówczas już nieużywana przez dziesięciolecia - doprowadziła do usunięcia wtórnych i dzikich nasadzeń roślinności i licznych „wkroczeń” na mur zbudowanych przez mieszkańców. Interesujące i dające pogląd na filozofię postępowania Towarzystwa Pro-Jerozolimskiego były uzasadnienia tego rodzaju działań - Ashbee argumentował, że Towarzystwo miało obowiązek chronić takie publiczne historyczne przestrzenie przed prywatnym rozwojem. Wskazywało to na istniejące głębokie zróżnicowanie między przestrzenią publiczną i prywatną, co z kolei pozwoliło bezwzględnie usuwać niepożądane zdaniem decydentów części osmańskiej tradycji Jerozolimy. Nie zmieniło to faktu, iż tak pokierowana kwestia zachowania murów i odtworzenia ścieżki dozorowej przez Ashbee'ego również uczyniła z tego elementu substancji urbanistycznej nowoczesną formę atrakcji parahistorycznej.

\section{PODSUMOWANIE I WNIOSKI}

Program przebudowy Jerozolimy i wynikające z tego konsekwencje dla układu urbanistycznego miasta są w dzisiejszej ocenie nie tylko wielkim eksperymentem architektoniczno-krajobrazowym, ale najczytelniejszym dowodem możliwości władz brytyjskich w kontekście kolonialnym. Obejmując bowiem kontrolę nad całym procesem przebudowy miasta oraz wyznaczając kierunki rozwoju poprzez przeniesienie kompetencji decyzyjnych w zakresie planów zabudowy z gminy na administrację kolonialną, brytyjscy urzędnicy stworzyli specyficzny system nadzoru, który skonsolidował moc kreowania układu miasta w rękach planisty. Kompetencje te wkrótce zostały rozszerzone poprzez ustanowienie lokalnych kodeksów budowlanych w celu dyktowania, w jaki sposób będą opracowywane projekty, wprowadzenie systemu zezwoleń oraz kontroli, które projekty będą realizowane. Działania te były wsparte całym aparatem administracyjno-prawnym dysponującym systemem grzywien i zdolnym karać tych, którzy zignorowaliby rządowy plan urbanistyczny ${ }^{32}$. Władza brytyjska, w tym Komisja ds. Planowania Miasta (ang. Town Planning Commission), działająca w zakresie kontrolowania rozbudowy była pełna; miejscowa ludność nie mogła odwołać się od procesu budowlanego, chyba że za pośrednictwem brytyjskich agencji rządowych ${ }^{33}$. Było to jedno z restrykcyjnych narzędzi brytyjskiej kontroli nad układem religijno-etnicznym Jerozolimy dążącym do przemodelowania istniejącego układu wynikającego z tradycyjnych podziałów.

Wprawdzie kwestie te wymagają dalszych badań, jednak przy tego rodzaju posunięciach mających ogromny wpływ na układ urbanistyczny miasta władze mandatowe kierowały się ewidentnym szowinizmem - brytyjscy planiści mocno wierzyli, że ówczesnym mieszkańcom Mandatu Palestyny (zarówno Arabom, jak i Żydom oraz chrześcijanom) brakowało poczucia „świadomości obywatelskiej” oraz kultury życia miejskiego i kreowania przestrzeni 
w rozumieniu zachodnioeuropejskim. Jak Ashbee wyjaśnił w jednym ze swych listów: „Impuls u muzułmanina, aby budować, był zawsze inny niż nasz. Nigdy też nie był on w stanie wymyślić konkretnych rozwiązań ani w strukturze, ani w polityce. Tworzył piękne fragmenty, splatał je razem, wykonał wykwintne wzory, które powinny pomóc w jego śnie, a potem usiadł i sobie śnił"34.

Ignorując tego rodzaju opinie, ówcześni decydenci ze Storrsem i Ashbee’em na czele w zasadzie odrzucali fakt, iż poza murami Starego Miasta powstały wcześniej jakieś nowe budynki i dzielnice, w których żyło 2000-2400 muzułmanów, 20000 Żydów i 5000-6000 chrześcijan. Pomijano fakt, iż wzrostowi liczby ludności poza murami miasta w drugiej połowie XIX w. towarzyszyła budowa nowoczesnych obiektów użyteczności publicznej właśnie w nowych dzielnicach Jerozolimy. Był to m.in. zbudowany w 1890 roku szpital miejski oraz szereg innych miejsc takich jak choćby park miejski (1891), muzeum (1901), teatr (1901), publiczne toalety i strefa publicznego wypoczynku - kawiarnie oraz księgarnie. Nie rzutowało to na kwestię, iż lekceważąca wobec ludności miejscowej postawa Ashbee'ego ujawniła jego głęboką ignorancję co do wspomnianych inwestycji i działań szerokorozumianej gminy jerozolimskiej oraz miejscowej izby handlowej w zakresie promowania rozwoju miasta w późnym okresie osmańskim ${ }^{35}$. Opierał się on bowiem na swej zasygnalizowanej powyżej orientalistycznej wierze w niezdolność osób z nieeuropejskiego kręgu kulturowego do kreowania nowoczesnościj ${ }^{36}$.

Tego rodzaju podejście władz brytyjskich i samego Storrsa do kwestii zmiany istniejącej substancji miasta i nadania jej archaicznego i modernistycznego zarazem stylu może dziś szokować, ale z punktu widzenia nauk nie z zakresu architektury, ale historycznych - co paradoksalne - ma pewne uzasadnienie ${ }^{37}$. Stosunek do „niewłaściwych” nawarstwień urbanistycznych w Jerozolimie opierał się bowiem na pewnym mechanizmie znanym w naukach historycznych - narracja jest zazwyczaj postrzegana nie tylko jako środek prezentacji dowodów, ale jako narzędzie organizujące rozumienie poprzez wyobraźnię historyczną ${ }^{38}$. Skoro więc wizja bądź wyobrażenia na temat przeszłości są opisywane dzięki pracy wyobraźni i wymagają uobecnienia nieobecnych wydarzeńn ${ }^{39}$, to w przypadku tego rodzaju kreacji często sprowadza się ona w najlepszym razie do fantasmagorii. Taki twórczy anachronizm wskazuje nam dziś jednoznaczny kierunek działań brytyjskich urbanistów na początku lat 20. XX w. w Jerozolimie i jednocześnie dowodzi, że dokładność odnosząca się do doktrynalnie rozumianej historii nie zawsze była najważniejszą wartością w ich działaniach. Osobnym elementem tego rodzaju działań jest fakt, iż np. wspomniane wcześniej ceramiczne znaki drogowe w języku angielskim, arabskim i hebrajskim ukazywały zmodyfikowaną kulturowo wizję historii Jerozolimy, zmieniając niejako obszar Starego Miasta w rodzaj żywego muzeum pod auspicjami brytyjskich władz mandatowych.

Nowa Jerozolima stała się jednak w okresie lat 20. i 30. XX w. jednym z najmodniejszych i najbardziej prestiżowych miejsc pod względem działań architektonicznych. Empire State Building w Nowym Jorku i budynek towarzystwa YMCA w Jerozolimie ${ }^{40}$ mają wiele wspólnego. Obie te budowle były najwyższymi w tych miastach w owym czasie, zostały 
zaprojektowane przez tego samego architekta - Arthura Louisa Harmona. W tym samym nurcie znalazły się gmachy: The Rockefeller Museum, The Hadassah Hospital na Górze Scopus czy hotel King David. W zestawieniu jednak z prawdziwym oglądem rzeczywistości w Starym Mieście wyidealizowany świat orientu ustępował. Nowe dzielnice Jerozolimy pod względem architektonicznym stały się mieszanką elementów grecko-rzymskich, renesansowych, gotyckich, romańskich, neomauretańskich i mameluckich. Estetyka tego rodzaju została połączona w jedną eklektyczną strukturę, np. w przypadku hotelu Palace, który został zbudowany w latach 1928-1929 z inicjatywy Najwyższej Rady Muzułmańskiej i stał się symbolem przepychu nowej Jerozolimy. Zaprojektowany przez tureckiego architekta Nahasa Beya stał się jedną z najbardziej luksusowych budowli w Jerozolimie. Położony w niewielkiej odległości od Starego Miasta, w dole ulicy Agron (wcześniej Mamilla Road), budynek ten miał być wizytówką orientalnej architektury w Jerozolimie, zarówno pod względem wyglądu, jak i wygody ${ }^{41}$.

Rezultatem końcowym było spetryfikowanie obrazu Bliskiego Wschodu jako zamrożonego w czasie regionu, gdzie baśnie z tysiąca i jednej nocy i duch krucjat były elementem żywym, a orientalna architektura w duchu europejskim stała się kanonem. Znacząca przy tym rola przypadła właśnie Towarzystwu Pro-Jerozolimskiemu ze Storrsem jako jego prezydentem i Ashbee'em jako sekretarzem. Przemawiał za tym również szerszy interes brytyjskich kół decyzyjnych i rządowych - w zasadzie Towarzystwo aż do momentu jego rozwiązania w 1926 roku funkcjonowało jako półoficjalny organ rządu Jego Królewskiej Mości. 


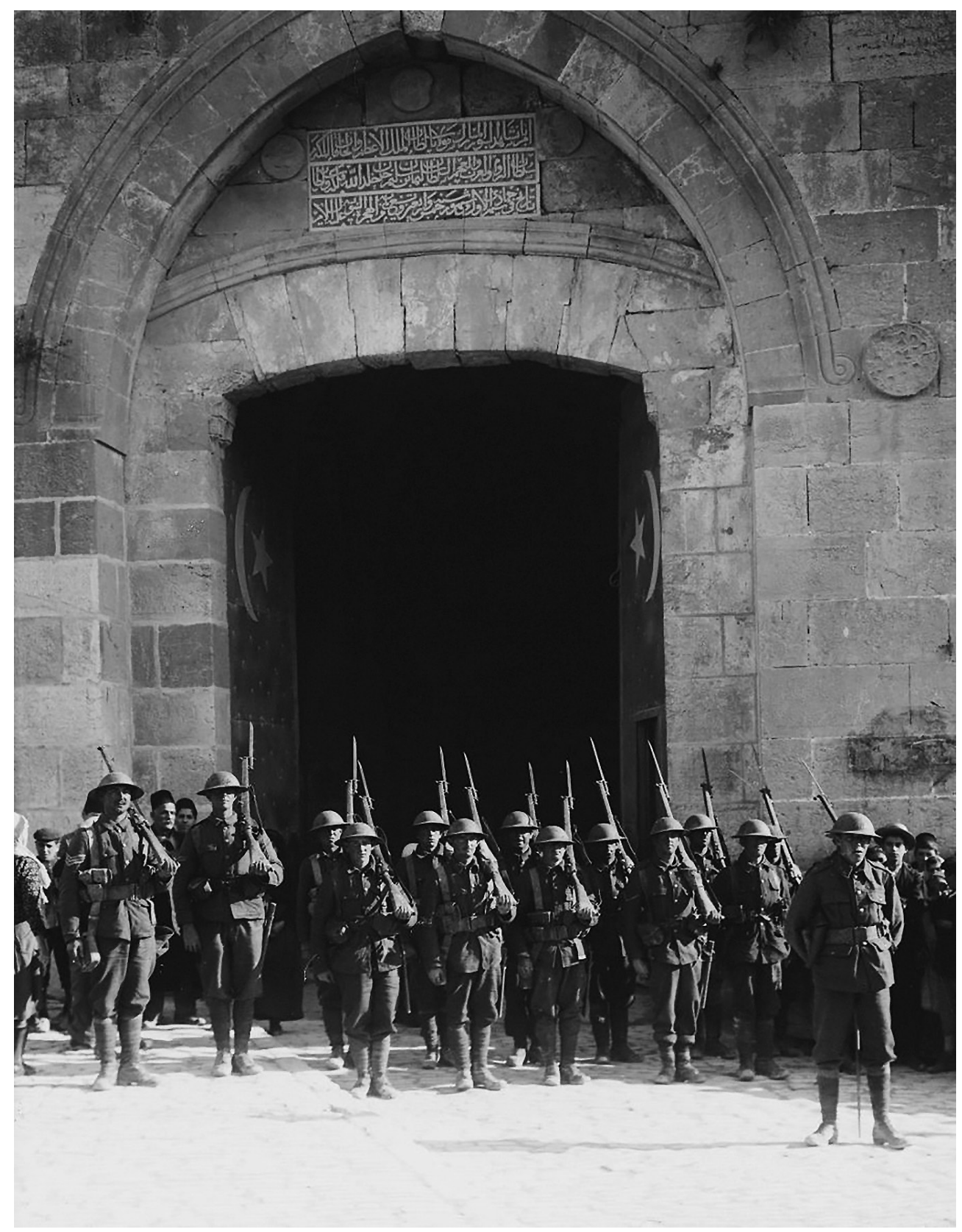

II. 1. 11 grudnia 1917 r. Oddziały brytyjskie po wewnętrznej stronie murów Starego Miasta przy Bramie Jaffajskiej w Jerozolimie (https://imgprx.livejournal.net) 


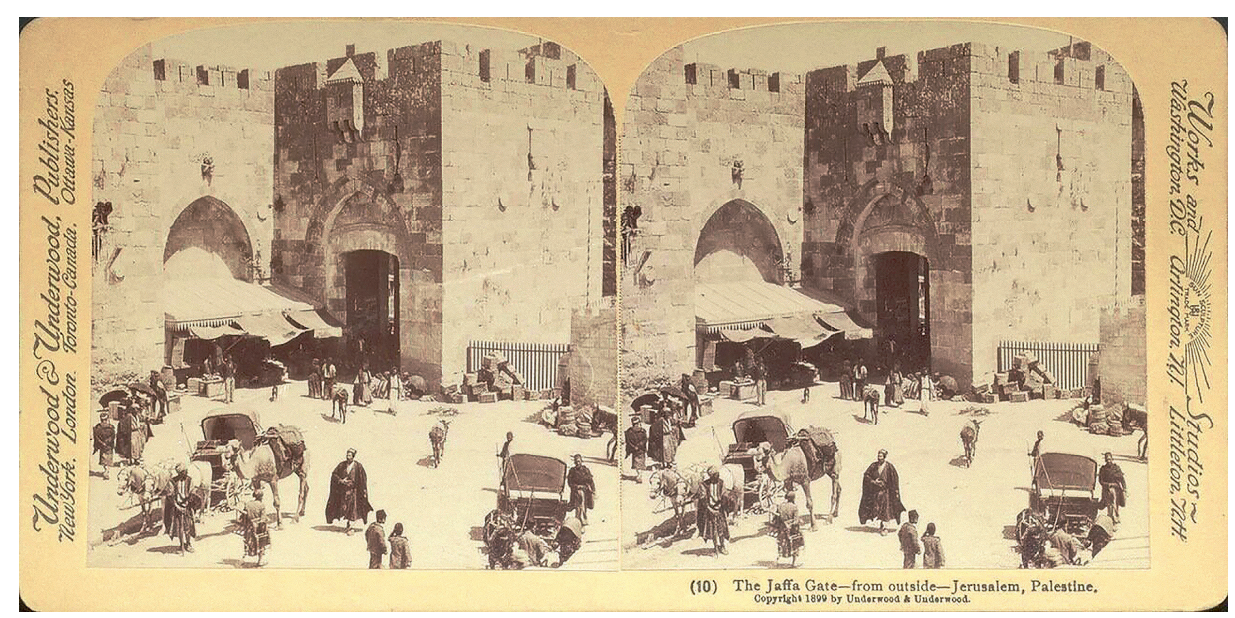

II. 2. Widok Bramy Jaffajskiej od strony zewnętrznej murów przed budową wieży zegarowej. Karta stereoskopowa z 1899 r. (ze zbiorów prywatnych autora)

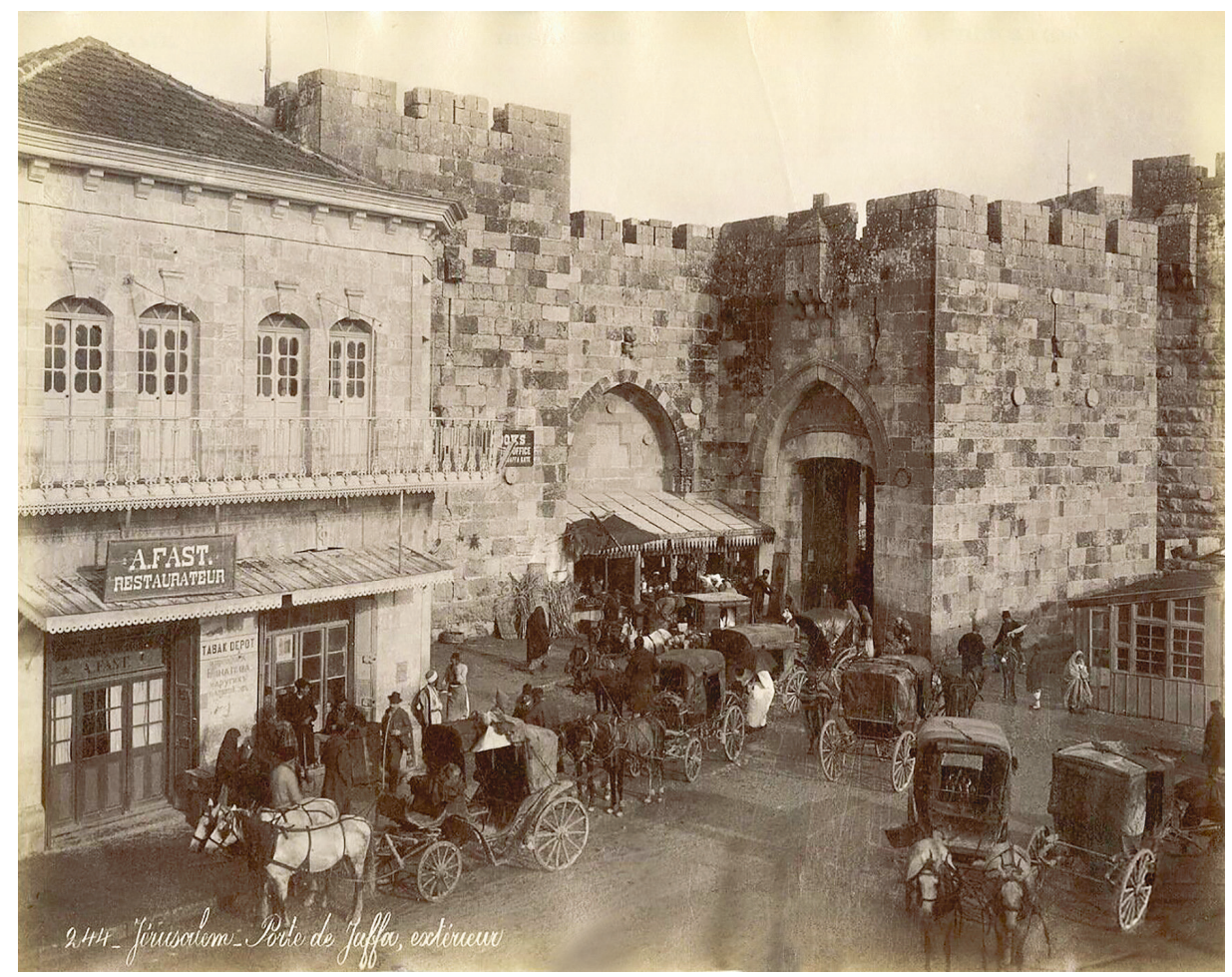

II. 3. Brama Jaffajska od strony zewnętrznej murów Starego Miasta około 1900 r. - widoczny wyraźnie stan rozwoju zabudowy (ze zbiorów prywatnych autora) 


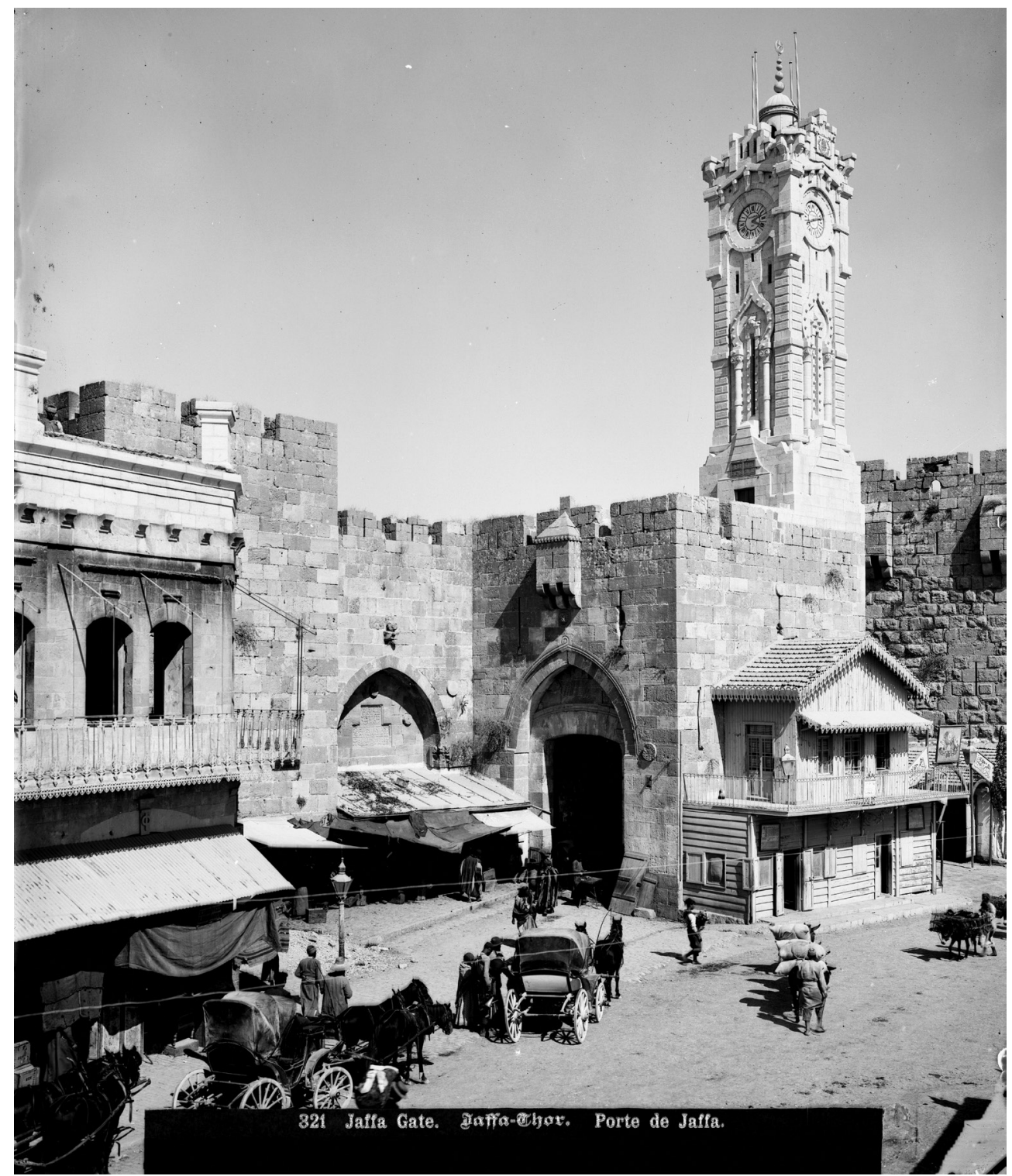

II. 4. Brama Jaffajska widziana od strony zewnętrznej murów Starego Miasta już z dobudowaną przez Osmanów wieżą zegarową (https://upload.wikimedia.org/wikipedia/commons/c/c0/Jerusalem_Jaffa_Gate-19th-clock.jpg) 


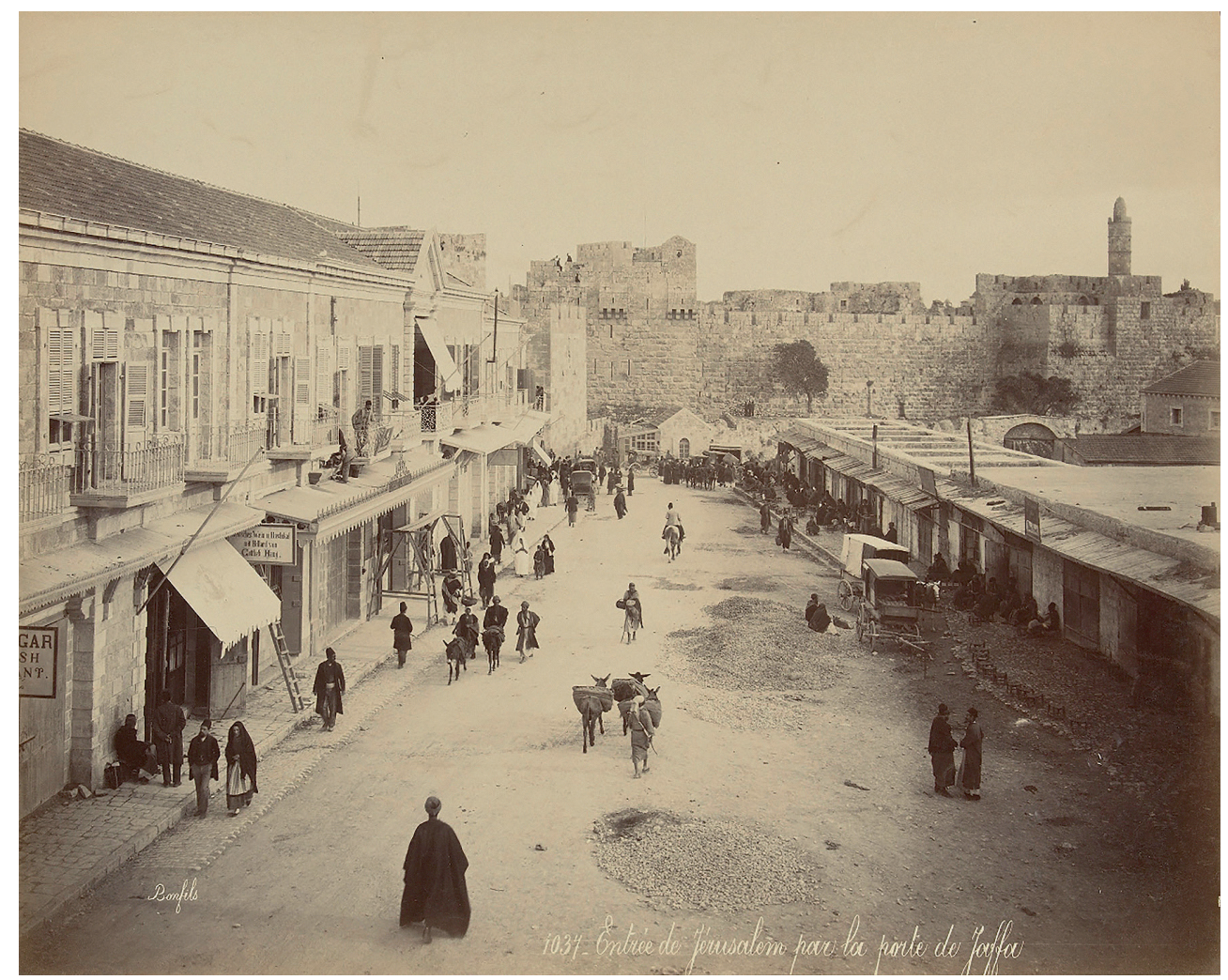

II. 5. Osmańska zabudowa w rejonie na zewnątrz murów Starego Miasta przy ulicy wiodącej do Bramy Jaffajskiej (ze zbiorów prywatnych autora) 


\section{1}

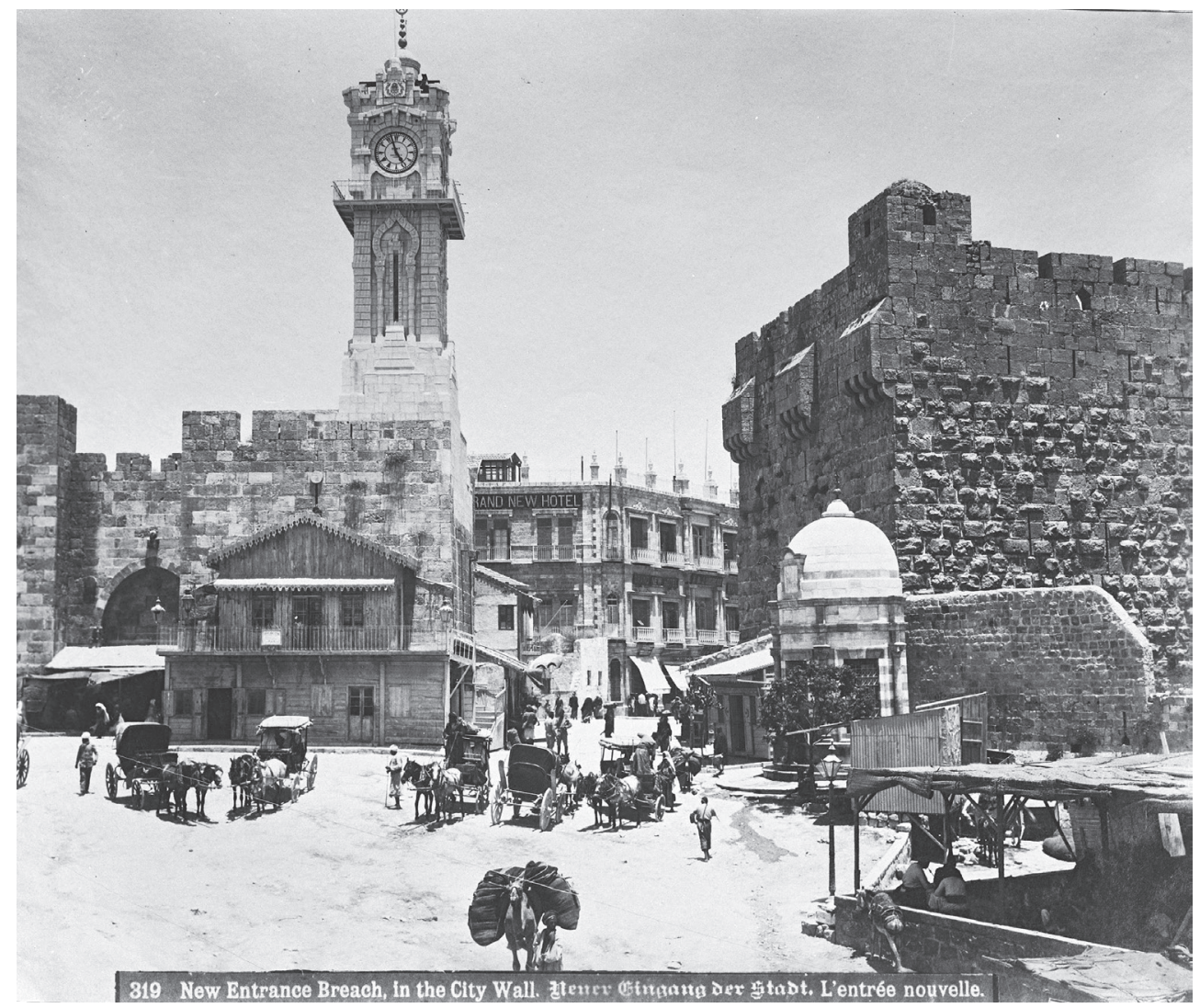

II. 6. Wyrwa w murach miejskich wykonana z okazji wjazdu cesarza Wilhelma II z widoczną Bramą Jaffajską z dobudowaną wieżą zegarową (https://upload.wikimedia.org/wikipedia/commons/b/ bb/THE_JAFFA_GATE_IN_THE_OLD_CITY_OF_JERUSALEM._\%28COURTESY_OF_AMERICAN_ COLONY\%29_D826-106.jpg) 


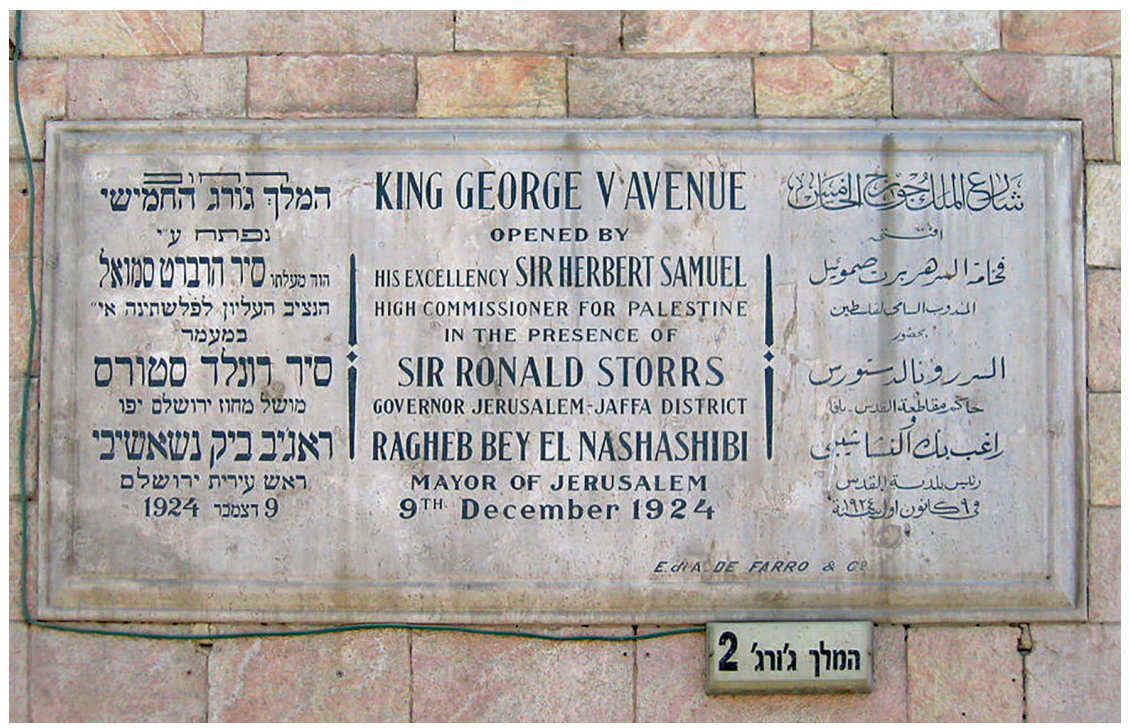

II. 7. Trójjęzyczna tablica upamiętniająca dedykowanie jednej z głównych ulicy Jerozolimy królowi Jerzemu V (fot. autor)

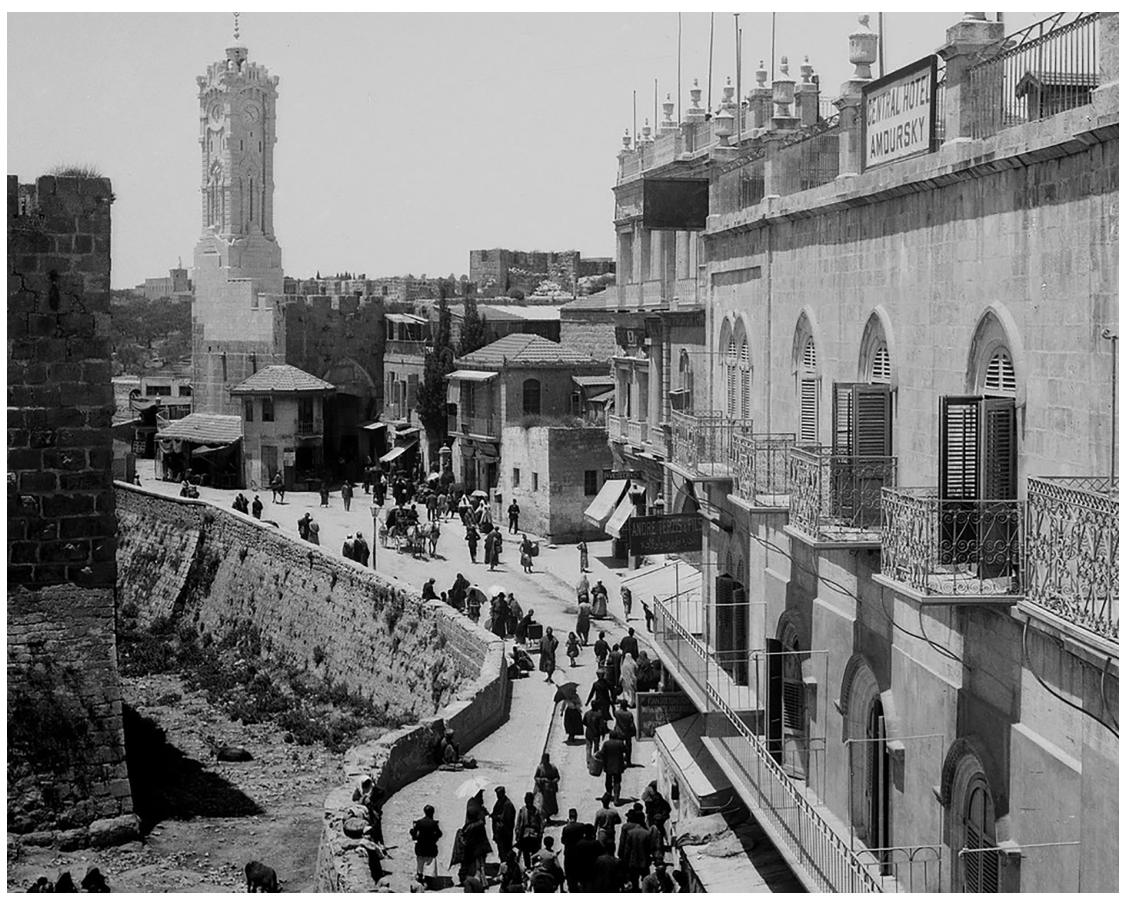

II. 8. Brama Jaffajska tuż przed zburzeniem wieży zegarowej, 1920 r.

(ze zbiorów prywatnych autora) 


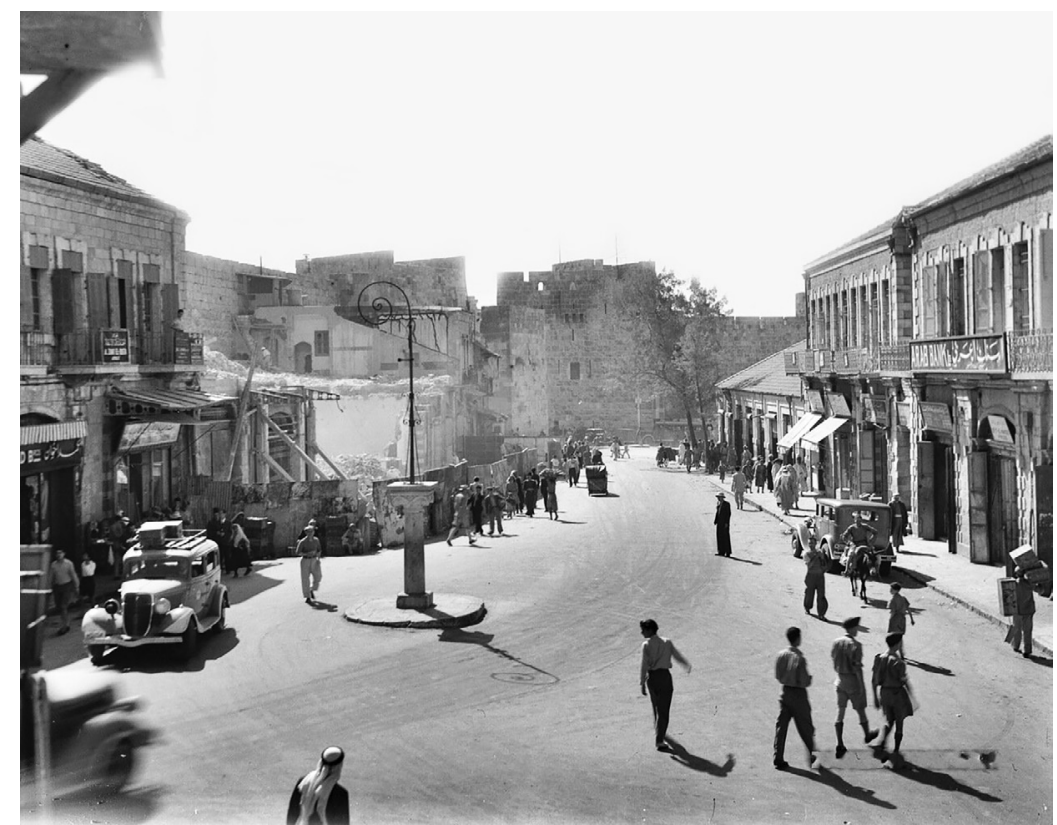

II. 9. Rozbiórka budynków w okolicach Bramy Jaffajskiej, 1944 r. (ze zbiorów prywatnych autora)

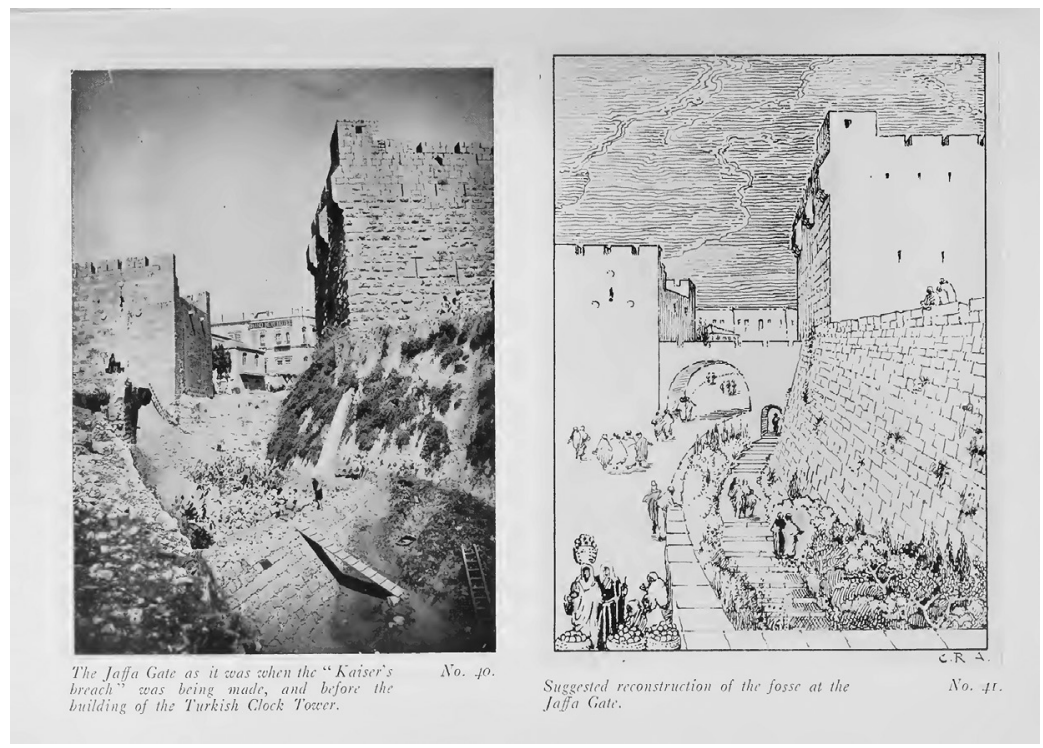

II. 10. Studia stanu zabudowy Bramy Jaffajskiej i planowanych prac (źródło: Jerusalem, 1918-1920: Being the Records of the Pro-Jerusalem Council during the Period of the British Military Administration, C.R. Ashbee (red.), London 1921) 
64

กิ

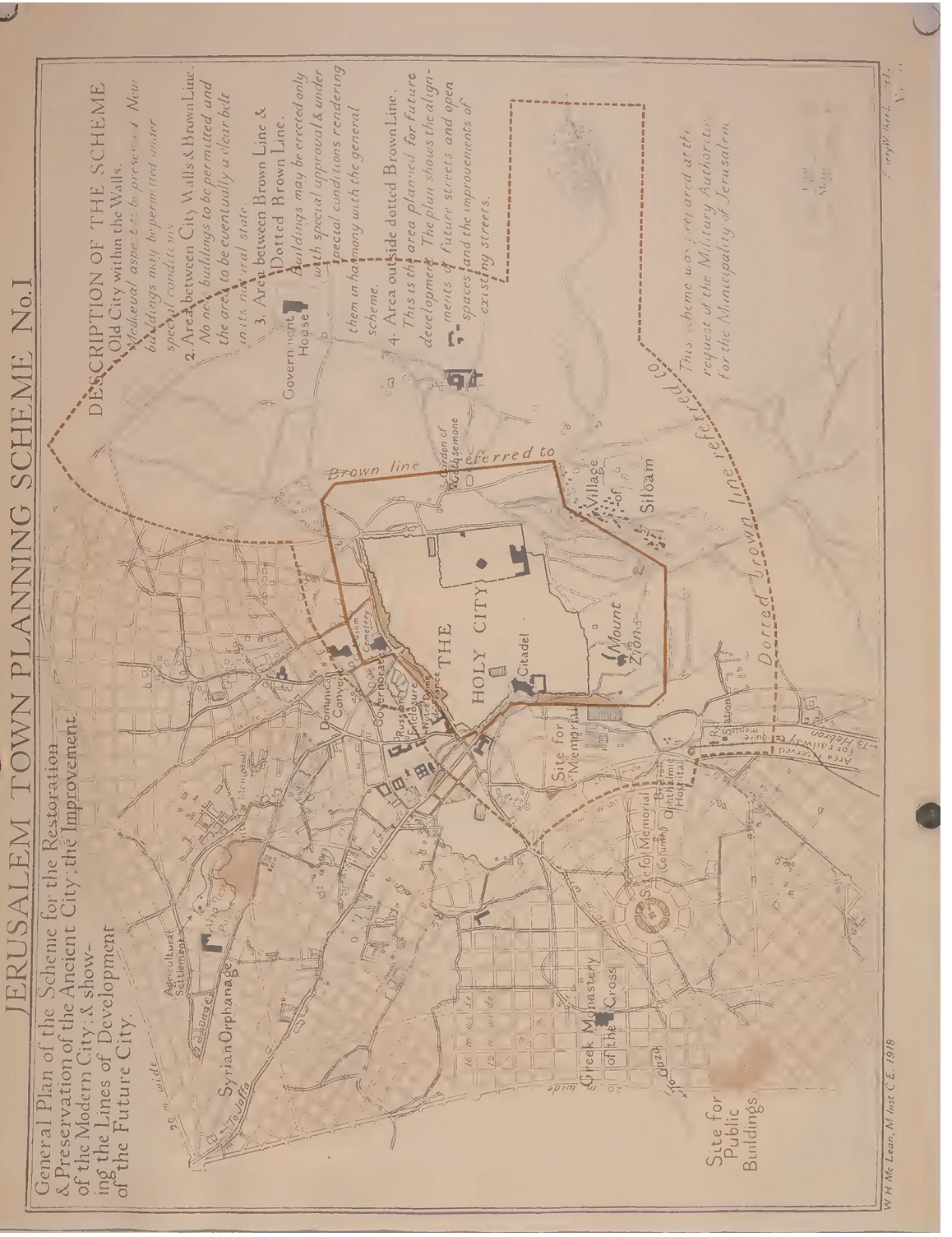

귁

$\infty$ न

귀

ह่ 응

호

ปั

웡 잉

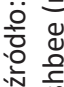

㐫 $\frac{5}{\frac{5}{4}}$

हे वे

잉

ํำ

霥

蛋

ह

३ำ

응 홍

ब.

楚

突 \&

告

을 웅

गे 인

¿

芩

:

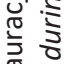

䒿

$=5$

胥

तु है

공

ำ

ป ำ

a

$\sum \frac{1}{5}$

3

产 옹

\%

담 $\frac{1}{5}$

ㄱ. 올 
65
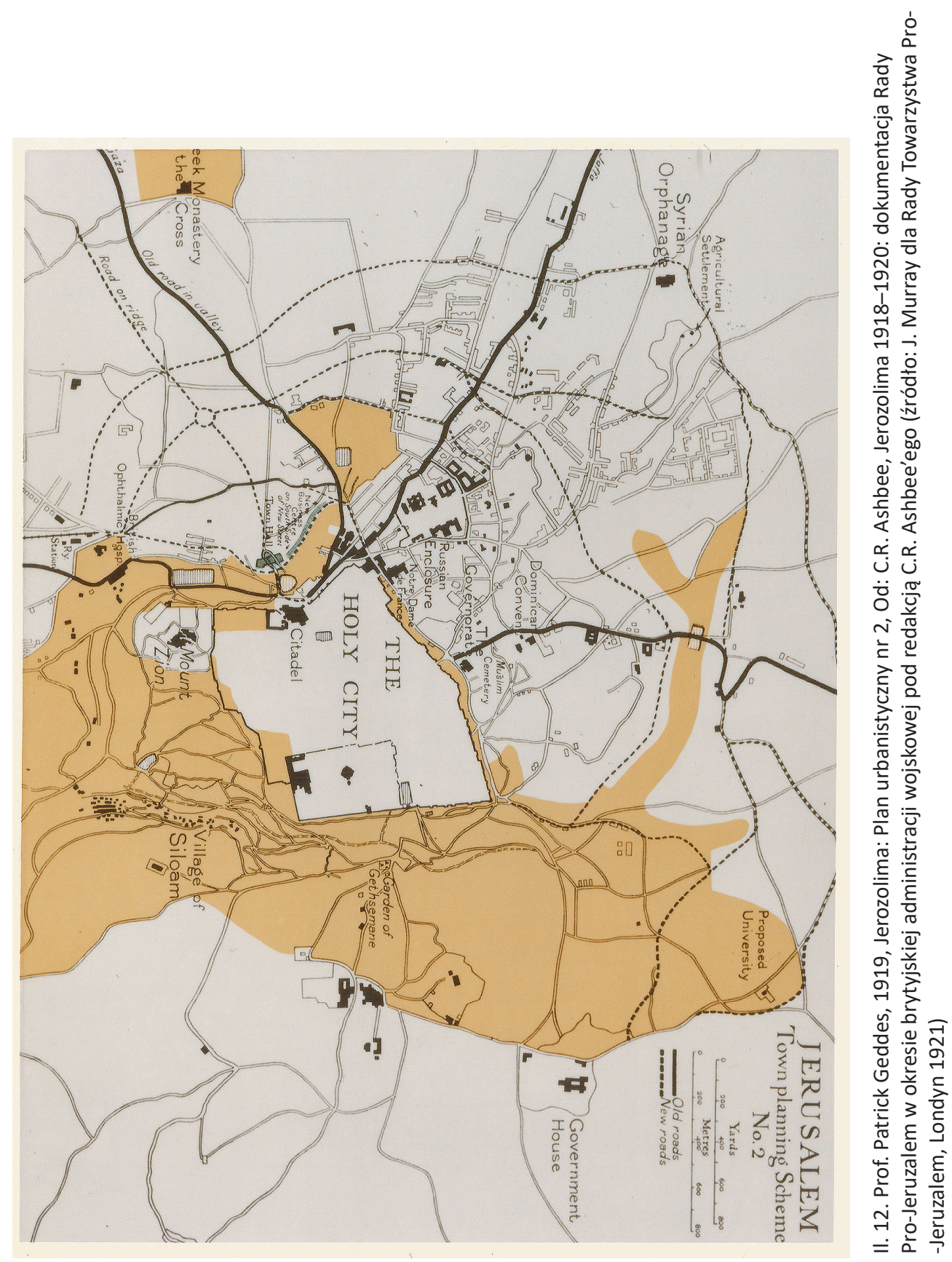


\section{PRZYPISY}

1 „Daily Sketch”, December 1917.

2 N.E. Roberts, Dividing Jerusalem British Urban Planning in the Holy City, Journal of Palestine Studies 2013, 42(4), s. 7-26.

3 Ibidem.

4 S. Goldhill, Jerusalem: City of Longing, Cambridge 2008, s. 172-174.

5 Jerusalem Municipal Archives (JMA), 361, Pro-Jerusalem Society, Minutes, nr 1, Jerusalem, September 6, 1918. W skład powołanego 6 września 1918 roku zarządu Towarzystwa weszli: Ronald Storrs, Ferdinando Diotallevi, Dr Eder (reprezentant społeczności żydowskiej), Patriarcha Ippolytos (reprezentant greckiego kościoła ortodoksyjnego), Kamil Effendi Husayni (Wielki Mufti Jerozolimy), Musa Kasim Pasha (prezydent rady miejskiej), S.G. Salama (wiceprezydent rady miejskiej), biskup Kud (reprezentant ormiańskiego kościoła ortodoksyjnego), ksiądz Abel, C.R. Ashbee, mjr Richmond oraz J. Spafford. Skład tego gremium zmieniał się wielokrotnie.

6 B. Wasserstein, The British in Palestine: The Mandatory Government and Arab-Jewish Conflict, 1917-1929, Oxford 1991, s. 20.

7 R. Mazza, Jerusalem: From the Ottomans to the British, London 2009, s. 129.

$8 \mathrm{H}$. Kendall, Jerusalem: The City Plan, Preservation and Development during the British Mandate, 1918-1948, London 1948, s. 6.

9 National Archive, London, NA, CO 1069/743.

10 R. Home, British Colonial Town Planning in the Middle East: The Work of W.H. McLean, Planning History: Bulletin of Planning History Group 1990, 12(1), s. 6.

11 N.H. Rubin, Geography, Colonialism, and Town Planning: Patrick Geddes' Plan for Mandatory Jerusalem, Cultural Geographies 2011, 18(2), s. 235.

12 https://israeled.org/ronald-storrs-appointed-military-governor-jerusalem/

${ }^{13} \mathrm{https} / / /$ www.mwme.eu/essays/index.html

${ }^{14}$ R. Storrs, Orientations, London 1937, passim.

15 https://israeled.org/ronald-storrs-appointed-military-governor-jerusalem/

16 Jerusalem, 1918-1920: Being the Records of the Pro-Jerusalem Council during the Period of the British Military Administration, C.R. Ashbee (red.), London 1921, s. 62.

17 N.H. Rubin, Geography, Colonialism and Town Planning: Patrick Geddes' Plan for Mandatory Jerusalem, Cultural Geographies 2011, 18(2), s. 235 i następne.

18 M. Klein, Lives in Common. Arabs and Jews in Jerusalem, Jaffa and Hebron, London 2014, s. $15-16$.

19 Tym samym działania te przyczyniły się do odbudowy cechu tkaczy w Jerozolimie. Do pewnego jednak stopnia miało to i pozytywne skutki społeczne - przynajmniej zdaniem administracji brytyjskiej, gdyż aby zachować i chronić zabytki architektury bądź je przebudowywać i zmieniać, potrzebna była siła robocza. Powołane przez Storrsa Towarzystwo 
Pro-Jerozolimskie uważało, że warunki wojenne zapewniły taką właśnie siłę roboczą, nie opartą na Brytyjczykach, ale na rosnącej populacji uchodźców w samej Jerozolimie. Dzięki temu do pewnego stopnia rozwiązano kwestę bezrobocia. Te jednak problemy nie leżały w obszarze zainteresowania ani ówczesnych mediów, ani społeczeństwa brytyjskiego, ani samego Storrsa.

20 https://www.haaretz.com/1.5138549

${ }^{21}$ Wieża zegarowa została zbudowana z wapienia wydobywanego z pobliskiej jaskini Sedekiasza i była zwieńczona ozdobnym dachem, poniżej którego znalazły się cztery tarcze zegara, zorientowane na główne punkty geograficzne. Tarcze wschodnia i zachodnia pokazywały czas oficjalny (czas europejski), natomiast północna i południowa - czas lokalny. Nad tarczami zegara znajdowały się dzwon oraz symbol półksiężyca i gwiazdy wskazujący na panowanie w mieście Imperium Osmańskiego.

${ }^{22} \mathrm{Na}$ terenach dzisiejszego Izraela i Autonomii Palestyńskiej znajduje się siedem takich wież zegarowych: w Safed, Akce, Hajfie, Nazarecie, Nablusie, Jerozolimie i w Jaffie. Fakt, że Brama Jaffajska w Jerozolimie została wybrana na miejsce wieży zegarowej, wskazujący na duże znaczenie tego elementu architektury miasta w owym okresie.

${ }^{23}$ S. Goldhill, Jerusalem: City of Longing, Cambridge 2008, s. 146-147.

24 Ibidem.

25 Znamiennym przy tym jest fakt, iż i ta wieża zbudowana przez Brytyjczyków została ostatecznie zburzona w roku 1934. „The Palestine Post”, September 27, 1934.

26 https://www.loc.gov/item/mpc2004000748/PP/

27 https://mfa.gov.il/mfa/mfa-archive/1999/pages/focus\%20on\%20israel-\%20jerusalem\%20-\%20architecture\%20in\%20the\%20b.aspx

28 Ibidem.

${ }^{29} \mathrm{H}$. Kendall, Jerusalem: The City Plan, Preservation and Development during the British Mandate, 1918-1948, London 1948, s. 6.

${ }^{30}$ R. Home, British Colonial Town Planning in the Middle East: The Work of W.H. McLean, Planning History: Bulletin of Planning History Group 1990, 12(1), s. 6.

31 Jerusalem, 1918-1920: Being the Records of the Pro-Jerusalem Council during the Period of the British Military Administration, C.R. Ashbee (red.), London 1921, podrozdział V.

$32 \mathrm{H}$. Kendall, Jerusalem: The City Plan, Preservation and Development during the British Mandate, 1918-1948, London 1948, s. 17.

33 JMA, 361, Pro-Jerusalem Society, Minutes, nr 1, Jerusalem, September 6, 1918.

${ }^{34}$ N. Shepherd, Ploughing the Sand: British Rule in Palestine, 1917-1948, New Brunswick 2000, s. 55-56.

35 Więcej na temat układu i funkcjonowania Jerozolimy jako miasta np. w: Y. Avci, V. Lemire, De la modernité administrative à la modernisation urbaine: une revaluation de la municipalité ottomane de Jérusalem (1867-1917), [w:] Municipalités méditerranéennes: les réformes urbaines ottomanes au miroir d'une histoire comparée (MoyenOrient, Maghreb, Europe 
méridionale), N. Lafi (red.), Berlin 2005; S. Tamari, Confessionalism and Public Space in Ottoman and Colonial Jerusalem, [w:] Cities and Sovereignty: Identity Politics in Urban Spaces, D. Davis, N. Libertun de Duren (red.), Bloomington 2011.

${ }^{36}$ D. Kroyanker, Jerusalem Architecture, New York 1994, s. 157.

37 R. Storrs, The Memoirs of Sir Ronald Storrs, New York 1937, s. 327.

38 Znamiennym przy tym pozostaje fakt, iż trwałość idei Storrsa oddziałuje na Jerozolimę w zasadzie do dziś. W roku 2010 w Eretz Israel Museum w Tel Awiwie zorganizowano pierwszą i jak do tej pory jedyną, wystawę czasową poświęconą działalności Storrsa. D. Karpel, Discerning Conqueror, Haaretz, 12 listopada 2010, [online] https://www.haaretz. com/israel-news/discerning-conqueror-1.324306.

39 D.H. Sacks, Imagination in history. Practicing New Historicism \& Hamlet in Purgatory, Shakespeare Studies 2003, 31, s. 64.

${ }^{40}$ W 1920 roku amerykańskie stowarzyszenie YMCA wysłało dyrektora Archibalda Harte’a do Jerozolimy. Szybko „zakochał się on w tym mieście” i chciał zbudować ośrodek, w którym wyrażą się trzy wielkie religie monoteistyczne. W 1924 roku wkład filantropa Jamesa Jarviego z New Jersey, amerykańskiej i brytyjskiej organizacji YMCA oraz społeczności żydowskiej w Manchesterze umożliwiły zakup ziemi w tym celu od greckiego patriarchatu. Trzy lata później brytyjski wysoki komisarz Lord Plumer położył kamień węgielny pod budowę tego budynku, a 18 kwietnia 1933 roku jerozolimska YMCA, powstała naprzeciwko hotelu King David, została otwarta przez ówczesnego feldmarszałka lorda Edmunda Allenby'ego, [online] http://tourguides0607.blogspot.com/2011/03/jerusalem-international-ymca-history-by.html.

${ }^{41} \mathrm{https} / / / \mathrm{mfa}$.gov.il/mfa/mfa-archive/1999/pages/focus\%20on\%20israel-\%20jerusalem\%20-\%20architecture\%20in\%20the\%20b.aspx 


\section{ŹRÓDŁA NIEPUBLIKOWANE}

Jerusalem Municipal Archives (JMA), Jerozolima, Izrael.

JMA 361, Pro-Jerusalem Society, Minutes, no. 1, Jerusalem, September 6, 1918.

National Archive (NA), Londyn, Wielka Brytania.

NA, CO 1069/743.

\section{BIBLIOGRAFIA}

Avcı Y., Lemire V., De la modernité administrative à la modernisation urbaine: une revaluation de la municipalité ottomane de Jérusalem (1867-1917), [w:] Municipalités méditerranéennes: les réformes urbaines ottomanes au miroir d'une histoire comparée (MoyenOrient, Maghreb, Europe méridionale), N. Lafi (red.), Berlin 2005.

„Daily Sketch”, December 1917.

Home R., British Colonial Town Planning in the Middle East: The Work of W.H. McLean, Planning History: Bulletin of Planning History Group 1990, 12(1).

https://israeled.org/ronald-storrs-appointed-military-governor-jerusalem

https://www.haaretz.com/israel-news/discerning-conqueror-1.324306

https://www.haaretz.com/1.5138549

https://www.mwme.eu/essays/index.html

https://www.loc.gov/item/mpc2004000748/PP/

https://mfa.gov.il/mfa/mfa-archive/1999/pages/focus\%20on\%20israel-\%20jerusalem\%20-

-\%20architecture\%20in\%20the\%20b.aspx

http://tourguides0607.blogspot.com/2011/03/jerusalem-international-ymca-history-by.html Goldhill S., Jerusalem: City of Longing, Cambridge 2008.

Jerusalem, 1918-1920: Being the Records of the Pro-Jerusalem Council during the Period of the British Military Administration, C.R. Ashbee (red.), London 1921.

Kendall H., Jerusalem: The City Plan, Preservation and Development during the British Mandate 1918-1948, London 1948.

Klein M., Lives in Common. Arabs and Jews in Jerusalem, Jaffa and Hebron, London 2014.

Kroyanker D., Jerusalem Architecture, New York 1994.

Mazza R., Jerusalem: From the Ottomans to the British, London 2009.

Roberts N.E., Dividing Jerusalem British Urban Planning in the Holy City, Journal of Palestine Studies 2013, 42(4).

Rubin N.H., Geography, Colonialism, and Town Planning: Patrick Geddes' Plan for Mandatory Jerusalem, Cultural Geographies 2011, 18(2).

Sacks D.H., Imagination in history. Practicing New Historicism \& Hamlet in Purgatory, Shakespeare Studies 2003, 31. 
Shepherd N., Ploughing the Sand: British Rule in Palestine, 1917-1948, New Brunswick 2000. Storrs R., The Memoirs of Sir Ronald Storrs, New York 1937.

Storrs R., Orientations, London 1937.

Tamari S., Confessionalism and Public Space in Ottoman and Colonial Jerusalem, [w:] Cities and Sovereignty: Identity Politics in Urban Spaces, D. Davis, N. Libertun de Duren (red.), Bloomington 2011.

„The Palestine Post”, September 1934.

Wasserstein B., The British in Palestine: The Mandatory Government and Arab-Jewish Conflict, 1917-1929, Oxford 1991. 